\title{
Spatio-temporal and hazard mapping of Earthquake in UAE (1984-2012): Remote sensing and GIS application
}

\author{
Mohamed Mohamed Yagoub
}

\begin{abstract}
Background: Assessment of historical earthquake events helps in revealing its distribution and coupling it with other geographical data provides a holistic view about areas and people that are affected. This study investigates the spatio-temporal distribution of earthquake events taking place in UAE and its effect on the population.

Results: Analyzing data from 1984 to 2012 showed that during the period of 28 years there were frequent earthquakes that occurred with intensity ranges from mild to moderate with the maximum magnitude of 5.1. Spatially, earthquake events were found clustered in the Emirate of Fujairah in the Eastern part of UAE (Oman Thrust). Temporally, the maximum number of earthquake events (49\% of the events) occurred in 2011 and this is in line with the United States Geological Survey (USGS) report that indicates in 2011 the earthquake activity reached its highest level in 20 years. Even the magnitude of the earthquakes is low, the frequency of being increased in the past few years coupled with urban development are point of concern and it becomes necessary to develop preventive measures such as hazard maps for the area. In this study seven parameters are used for generation of a hazard map, this includes geology, soil, slope, land use, historical earthquake events, fault line, and roads. GIS weighted overlay analysis is used to demarcate the earthquake risk zones.

Conclusions: The resulting map prepared will help in systematic and proper development of land use for community planning and mitigation policy. To the knowledge of the author, the research is the first attempt that integrates diverse GIS data to produce hazard map for the Eastern part of UAE and therefore it adds acknowledge about the area. The methodology could be adopted by other regions around the world.
\end{abstract}

Keywords: UAE; Earthquake; Hazard map; Remote sensing; GIS

\section{Background}

Earthquake hazards can be single, sequential or combined in their origin and effects. Each hazardis characterized by its geographic location, area, size or magnitude, intensity, speed of onset,and duration and frequency. These can come alone or be a triggering event for much awaited disaster to happen like landslide. Grunthal et al. (1999)carried out a study as a part of Global Seismic Hazard Assessment Program (GSHAP) in which he arranged a seismic hazard map for Europe, Africa and Middle East from individual area studies.

Correspondence: myagoub@uaeu.ac.ae

Department of Geography, College of Humanities and Social Science, United Arab Emirate University, 15551, Al Ain, UAE
These individual studies do not cover UAE but a hazard map was prepared (Safari Hojjat et al. 2011) for Zagros province of Iran by simulating the attenuated effect of the seismic hazard activity in there. For the geologically young Zagros Mountains (Miocene-Present), the major faults and folds were the source for drainage basins for the major rivers. The mobile rivers which respond to fault and folds shows more drendritic pattern and runs through NW-SE trend in the region. Abdalla and Al-Homoud (2004) took some input parameters for EQRISK consisting of Richter factors, geometry of source regions, rate of occurrence, annual probability of exceedance, and coordinates of location and carried a seismic hazard analysis for UAE but their study was only been limited to the anticipated peak ground acceleration with a $10 \%$ probability of being exceeded during time 
spans of 50, 100 and 200. Till date no such study has been conducted for UAE which states the earthquake hazard spatially as well as temporally for a specific time period. In our study the earthquake happened in Eastern UAE from 1984-2012 have been taken and are tried to show the answers of where and when it happened.

Remote sensing images (low-medium-high resolution) had been used to investigate before, during, and after earthquake situation particularly land surface change and assessment of damage (Champatiray et al. 2005; Lillesand et al. 2008; Roustaei et al. 2005). Change in features can be detected from images before and after earthquake due tonal differences, linearity (faults, folds), vegetation, and $3 \mathrm{D}$ characteristics. The strength of remote sensing is in its ability to reach inaccessible areas and covers large area in one image, this has the advantage to detect regional trend of fault/fold lines. Recent advances in remote sensing such as high temporal and spatial resolution helps in detail investigation of earthquake. Space technology is also used to predict earthquake using various theories such as midinfrared radiation, earthquake events, crust deformation, ionosphere electronic content, change in EM signals and Earth magnetic field (Alimohammadi 2005; BBC 2013; Heki and Ping 2005). The advantage of digital remote sensing images data is that they are geometrically and radiometrically corrected and comparison of them with other datasets can be done using GIS. Digitization, data calibration of analogue maps and field surveys plays an important role for computer processing of the images and to integrate into a GIS environment (Pirasteh et al. 2009). Remote sensing images are used for generation of Digital Elevation Models (DEM) and the DEM is an important input parameter for many disaster operations such as detection of regional geo-structural features (Pirasteh et al. 2011). One of the important role carried out through remote sensing is to unveil the secrets of earthquake occurrence by analyzing the earth's surface component. Thermal infra region of the electromagnetic radiation (EMR) of NOAA-AVHRR and Atmospheric Infrared Sounder (AIRS) of Aqua satellite is used nowadays to monitor atmospheric component and to understand the earthquake behavior (Pirasteh et al. 2014). There are many researches around the world for the comparison of different DEM's which are contradictory to each other. Hirt et al. (2010) compared ASTER GDEM to SRTM and a 9" DEM of Australia. They did not have a higher resolution DEM with which to compare, and resampled all the data to the 3" SRTM spacing. They noted a large number of artifacts in GDEM ASTER, and found its vertical accuracy to be $\sim 15 \mathrm{~m}$ compared to $\sim 6 \mathrm{~m}$ for SRTM. On the other hand, Hayakawa et al. (2008) analyzed a pre-release version of GDEM for Japan. They predicted that GDEM would provide a better alternative to SRTM because of the higher resolution, fewer missing data, and better topographic representation. Abrams et al. (2010) noted the many anomalies (clouds, "pits", and "bumps" or "mole runs") in GDEM, and that GDEM can contain large elevation errors on a local scale and should be considered "experimental" or "research grade". Faults, folds and thrust faults were digitally mapped on the basis of images and geotechnical elements. Study conducted on Zagros mountains using ETM imagery FCC and overlaying it with DEM indicates the closely spaced folds and faults showing the importance of remotely sensed data and their usage Ahmad and Pirasteh (2004).

Geographic Information System (GIS) had been used extensively in all phases of disaster- prediction, identification, response, mitigation, and recovery (Balaji et al. 2002; Laefer et al. 2006; Roy et al. 2000). The strength of GIS is in its ability to integrate diverse data, spatial analysis, visualization and the capability to link with external models (Henning 2011; Miles and Ho 1999). In this study GIS is used to prepare and fuse various parameters which were important and have a greater impact while considering a seismic event and preparing an output map for identifying the risk areas (hazard map). Such types of maps will be of direct benefit in setting planning rules to avoid development in areas with high risks. Apart from this, Information on ground motion is necessary to understand the behavior of buildings in earthquakes since it can cause a vast loss of life. Engineering parameters such as seismic data, structure, parcel and material type, foundation, ceiling, wall, floor, the interior and the exterior can form a basis to calculate the damage index (Pirasteh et al. 2015).

In the present time, many UAE cities reported tremors and mild shaking of buildings from two strong earthquakes (6.2 and 6.3 on the Richter scale) that hit Iran and Oman (Gulf 2013; Khaleej 2013). UAE has taken disaster as an important issue and it took many concrete steps to prepare for that. For example, in 2007, UAE established the National Emergency and Crises Management Authority (NCEMA) with the objective of dealing with disasters and coordinating with different concerned organizations (http://www.ncema.gov.ae/). Dubai has set building rules that put into account earthquake -buildings taller than 10 floors as well as schools and hospitals should be built to withstand quakes between 5.5 and 5.9 (The National, 2013). Other emirates had revised their building codes with respect to earthquake and more studies on building fragility in UAE started to appear (Mwafy 2010). On the public front, UAE had established many non-governmental organizations such as Sanid (http://www.sanid.ae/en/index.html) and Takatof (http://www.takatof.ae/). The move by the government and the public in UAE towards how to deal with disaster is a clear indication about the significance of the problem. 


\section{Preparation of Hazard Map}

The hazard maps should include information on the nature of the hazard (e.g. frequency and severity, topographical data, etc.), exposure inventory (e.g. population, buildings, highway, etc.), and the vulnerability of exposures to hazards (dense population, poorly designed buildings, low grade settlements, inadequate emergency response capacity, etc.). This combination of hazard, exposure, and vulnerability combines to define the nature of risk. There are a different ways to reveal earthquake shaking hazards and the severity of shaking and disaster triggered by it in a specific area. There are various application of an accurate hazard map like deciding insurance rates, business and land-use planning, estimations of stability and landslide potentials of hillsides, allocation planning of funds for education and preparedness for concerned general public and society. The hazard map will reduce geo-disasters impact and improve the relationships between geoenvironment and society (Wang 2014). The United States Geological Survey (USGS 2014a) shows many parameters while preparing any seismic hazard map for a particular region of study which includes historical earthquake data, quaternary faults, crustal deformation, strong motion data, etc. Since our study is limited to a unique area of UAE so we have included only seven main factors which have a major impact on our study region. The output map will highlight populated areas of eastern part of UAE while eliminating depopulated regions. It will more precisely show the areas with highest risk related to regional population distribution and major cities affected.

The main ingredients comprising the hazard parameter are geology, soil classification, slope, land use pattern, earthquake scenario, fault lines, and road network. There are many researches been done on the study of geology, soil etc. as a key factor for a seismic event to happen. This is a crucial parameter as described in the USGS official website. For that we have included these particular parameters for our research in UAE scenario.

\section{Geology}

Considering the geology of Eastern UAE, the features follow that of Arabian platform. The flatness of the terrain and covered with sediments of the Arabian Platform makes most part of the UAE (the western and central parts) virtually impossible for geologic and seismic investigations. Rest of the part is subjugated by the Semail Ophiolite which is covered by topographically high Oman mountains. It has not been possible to assess local seismicity till now because of low regional seismic network that exists in UAE. Information on the distribution of damage from past earthquakes and analysis of geological condition will give necessary vision to develop empirical relations needed to anticipate effects of future earthquakes (Borcherdt et al. 1991). Northern Oman and northeastern part of the
United Arab Emirates (UAE) is exposed by Late Cretaceous Semail ophiolite, where it forms the world's largest exposure of oceanic crust and upper mantle emplaced onto continental crust Glennie et al. (1974). High pressure rocks, including carpholite-bearing meta-sediments, garnetblue-schists and eclogites of continental crustal origin are exposed in north-eastern Oman, structurally beneath the ophiolite (Lippard 1983). Active tectonics in the broad Arabian Gulf region is caused due to Arabian-Eurasian collision. Brueckner and Medaris (1998) proposed a sinking intrusion emplacement model, with the peridotites being entrained as lenses into the continental crust from the mantle wedge above the subduction zone. Investigations had been carried out for the frictional properties of peridotite at realistic seismic slip rates and net displacements but lower normal stresses than expected at relevant depths. Unluckily a very little research has been conducted for the northern Oman Mountains on the topic of neotectonics, and no detailed field surveys for the Tertiary faults or assessment of their seismicity has been conducted. These faults comprises of structures like the Dibba Line (Glennie et al. 1990) and the Wadi Shimal and Wadi Ham Faults (Gnos and Nicolas 1996). These and associated faults stretch out within the Dibba- Masafi-Fujairah area of the northern UAE. Geological classifications are of special importance for seismic zonation in the region as compiled for flatland deposits and hillside materials. These will identify and differentiate units on the basis of physical properties and geologic characteristics useful for planning purpose.

\section{Soil}

Soil classification may be based on various sets of criteria, such as topographic position, landscape and sedimentological processes which may be taken into account while analyzing any hazardous events. It should be noted that the definition of soil units is based on soil association rather than on a single soil category. The basis of any geotechnical investigation is to model the rupture mechanism at the source of an earthquake, evaluate the propagation of waves through the earth to the top of the bed rock, determine the effect of local soil profile and thus develop a hazard map indicating the vulnerability of the area to potential seismic hazard (Kanli et al. 2006). The same concept has been taken care of in this study for UAE. Torripsamments which is clay rich soil type found in majority of the region is not susceptible for seismic activity and the contribution of it in any liquefaction study is nil while Torrifluvents are considered more prone to any seismic activity.

\section{Slope}

Earthquake induced inertial forces produce the slope instability which further proves to be a progressive 
development of slope displacements occurring for the duration of ground motion only. To obtain an evaluation of the induced displacement using analytical procedures accounting for time dependant seismic action, evaluation of slope response to earthquake loading should be carried out accordingly (Farghaly 2014). Regarding the population growth and expansion of urban areas, people are getting more close to the mountains in these areas without getting aware of the consequences at the time of major earthquake. The temporal and spatial distribution of the seismic forces in the soil mass is determined by response of slope under seismic loading which in turn depends on mechanical properties of the soil and the characteristics of the seismic input. In general, any construction been carried out on the vicinity of a hillside should be first studied and solution should be provided for anticipated problems. According to Lindell and Prater (2002) suggested that to reduce the hazard vulnerability, land use practices such as avoiding construction in hazard susceptible areas should be followed. They argued that government agencies should establish new rules and regulations which will encourage the adoption of appropriate land use practices and will prevent development in hazardous locations. They must also provide incentives that will encourage the people for moving to safer locations, or informing landowners about the risks and benefits of these locations throughout the community. Here the land use has been divided into five classes with high priorities been given to the settlements and oil tanks to reduce the loss of human lives in the event of any hazard occurrence.

\section{Historical Earthquake Events}

An attempt has been made to obtain historical earthquake data for a specific area of UAE and to relate these to the background seismicity; analyzing sequences of earthquake activity, performing statistical analysis of earthquakes (such as the frequency of occurrence of earthquakes with various magnitudes). Earthquake hypocenters provide a quick visual of earthquake activity and highlights concentration along local features, such as faults. A plot showing the areas surrounding each hypocenter within which damage occurred can provide decision makers a warning about the susceptible areas. These maps can be a great advantage to authority and the people who might look at the location of an earthquake and dismiss the importance because it did not appear to them. Online records of the USGS and UAE National Center for Meteorology and Seismology (NCMS) showed minor incidences of earthquake across UAE (NCMS-UAE National Center for Meteorology and Seismology 2014). Although USGS and NCMS provide up-todate information about earthquake incidence worldwide, the region, and in UAE, there are no historical chart linking the distribution of these incidences with the fatalities that have and may occur in future.

\section{Fault Lines}

The two fault lines falling in the study area comprises of Dibba fault line and Oman thrust. The Oman trust fault zone is found to be locus of major earthquake occurred in the area, a transition zone with slow slip and creep activity. This is based on the analysis and correlation of seismic historic data and detailed documentation of recent seismic events in the region. In eastern part of UAE, the Dibba fault zone defines the western and northern extent of the Ophiolite Nappes geological type. The identification of structures in the basement and overlying sedimentary cover of the western leading edge of the deformed thrust front belt that flanks the northern Oman Mountains in the UAE is critical for the earthquake study as high frequency of earthquake events occurred near it. These tectonic events involved the emplacement of a number of thrust sheets, each of which was emplaced from NE to SW onto the Oman Tethyan continental margin which had been rifted during the Permian to Late Triassic - Early Jurassic(Robertson and Searle 1990).

Much of the required information for one disaster can be considered as common to all disasters, both because of general requirements of access and evacuation but also because a named disaster such as an earthquake may generate multiple hazards (e.g. collapsed buildings, fires, road blockage, and utility interruption). In any disaster study, roads should be given an important weightage for the purpose of evacuation, emergency and mitigation (Laefer et al. 2006) and so for the proper planning and preparedness, it is considered as an important factor in our study too.

The prime concern of the present paper is to assess the seismic hazard in the Eastern part of UAE and prepare an earthquake hazard map for the area which poses a challenge to the engineers and authority for the mitigation and preparedness for any disaster plans.

\section{Objectives}

The main objectives of this study are:

- To study the temporal and spatial distribution of earthquake in UAE during the last 28 years and link this distribution with socio-economic data (data fusion).

- To generate a seismic hazard map and to identify the risk prone areas in Eastern UAE with consideration of spatio-temporal distribution of earthquakes from 1984-2012.

Eastern part of UAE has been a major region for many studies conducted before related to seismic activity Farshad et al. (2006); (Rodgers et al. 2006). The area include many cities like Fujairah, Masafi and major oil export zone also which needs to be mapped. Since two important and active fault lines passes through the region making it more prone 
for earthquake events and this can be confirmed by analyzing the data of past earthquakes been happened in the area making it suitable for our study. The study covering an approximate area of $\left(4000 \mathrm{~km}^{2}\right)$ bounded between the latitude of $24^{\circ} 50^{\prime} \mathrm{N}$ and $25^{\circ} 40^{\prime} \mathrm{N}$ and longitudes of $56^{\circ}$ $00^{\prime} \mathrm{E}$ and $56^{\circ} 50^{\prime} \mathrm{E}$ (Figure 1). This area covers many regions within UAE and Oman but since our study is not limited to any political boundary so it will be considered as one natural boundary. However, majority of the area falls within Emirate of Fujairah. It has a total population of 182,000 and almost $77 \%$ of them lives in Fujairah main city $(140,000)$ (Fujairah Statistics 2013). The area comprises mainly of the Hajar mountains and has a large diversity of flora and fauna making it a major ecoregion.

\section{Data Used}

Earthquake data used in this study was obtained from the Bulletin of the International Seismological Centre (ISC) event catalog which contains data from 1904 to 2013 (ISC- International Seismological 2013). Cleaning the data for the desired period gave an output with low to medium magnitude occurred in the area. The USGS Earthquake Archive Search \& URL Builder was also utilized for data collection (USGS 2013).
Elevation data(ASTER DEM) was obtained from the (USGS Earth Explorer 2013). This data was considered for our study due to non-availability of SRTM for this particular area. Land use was prepared with the Google earth images for the year 2013. The study area is mostly covered by mountains and the land use made available to the research by the authority was of 2005 and can be considered out of date. Therefore, high resolution Google images were used for preparing the land use layer (viz. five classes namely, Green areas, Water bodies, Rock Outcrop, Oil Tank, Built-up) through Google Earth as it provides facility of Zooming In and Out while considering the time slider which help the author to see into the past images $(2005,2006,2010,2011$, 2013). Population density (cities, villages) data were obtained from the UAE Statistical Center. Geology and soil layers were digitized manually on geo-referenced maps of scale 1:550000 provided by the university. Fault lines, important infrastructure (schools, roads, hospitals, malls, etc.) were compiled from various sources such as Fujairah Municipality. Road network was obtained from Fujairah Municipality and can be considered to be very accurate as many earlier researches have been conducted in this part of UAE using this data. The coordinate system for the input and output raster as well as

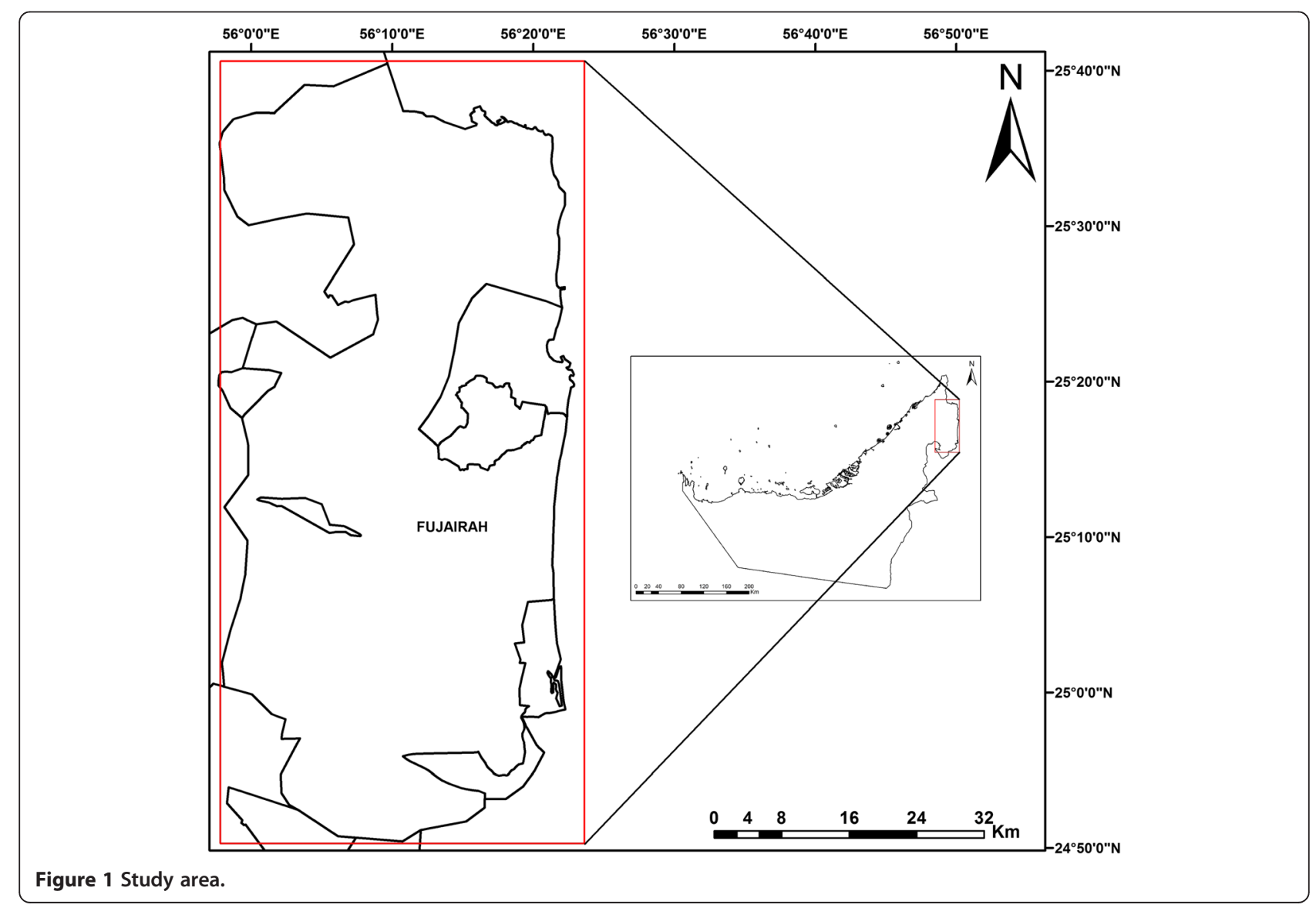


vector has been kept as World Geodetic System 1984 (WGS84) Geographic Coordinate System (GCS) to minimize the deformation of the projections to distance and area calculations with the spatial data.

\section{Methodology}

The approach taken in this research is based on some criteria and findings of earlier researches which took place in this type of area and conditions (Table 1). Combining both GIS and remote sensing resulted in understanding the phenomenon of earthquake and creating a hazard map for risk prone area that will be helpful for future planning and further strategies (Figure 2). Therefore, the parameters visualized by using GIS and maps are classified into 3 classes of representation in this study. After determining criteria value ranges, the ranking of the class values from 1 to 3 is assigned with respect to scientific codes and assumptions.

The seven criteria of the study are also basic components of attenuation modeling process and can also be mapped. In this study it is aimed to acquire the maps of all the criteria by classifying them according to related codes (Table 2). Classification is done in preparing the map as to help the decision makers understand the situation and distribute the components rapidly by just looking at the map. The whole process for GIS data and analyses are carried out by using the ArcGIS 10 software Model Builder tool. In this way an automated GIS system may also be an important constituent for these kinds of studies. The weight and individual class/features shown in Table 2 are made flexible to change through a user interface.

The factors that are been taken are basic parameters for any seismic study. The geological aspect of the study region shows that there are many classifications in it such as Ultrabasics-peridotite, mixture of Ultrabasic and Gabbroic rocks, Gabbros and Ultrabasics etc. The major influence of geologic conditions on both strong shaking characteristics and resulting damage pattern are included in this study.

The two soil types are found in the region namely, Torrifluvents-torriorthents and Rock outcrops-torripsamments.
Many studies have been conducted on the soil effect for seismic activities and came to conclusion that the clay rich soil type are not susceptible to liquefaction and make no contribution to the calculation of the any seismic hazard Index. This proves our study as torripsamment soil type is a clay type and thus is given less weightage while calculating the hazard Index. Attention is particularly drawn to the fact that the intensity of shock due to an earthquake could vary locally at any place due to variation in soil conditions.

The response of a slope is determined by the two forces viz. temporal and spatial distribution of the seismic forces in the soil mass, which further depends on the seismic input characteristics and on the mechanical properties of the soil. This makes slope an important aspect for the study of any earthquake mapping in this region. The slope was generated from ASTER DEM with a resolution of $30 \mathrm{~m}$. The slope is calculated in percentage with reclassified into three classes. The highest weightage was assigned to the steepest slope range as it will be a devastating condition for the settlements residing beneath it as in case if an earthquake triggers a landslide.

The land use patterns replying to an earthquake occurrence is very important while making an earthquake hazard map. The land use pattern for the study region has been taken extensively and have been classified into five types viz. Green areas, Rock outcrops, Water body, oil tanks \& ports and Built-up. Google earth images were used to digitize the existing land pattern into five classes as the images available in that are of high resolution and can be zoomed in and out to get a clear vision of the area. For any research carried out for an earthquake the main consideration is to have minimum loss of life and property. Taking this into mind the built-up area and oil tanks have been given the highest weightage followed by rock outcrops, water body, and finally green areas.

The seismicity of UAE in particular has received little attention. Considering its location on the southeastern part of the Arabian plate and the geological, tectonic and the limited seismicity information, the presence of a relatively low-to-moderate seismic hazard in this region is quite evident. Since, the Seismic wave travel on

Table 1 Criteria for Hazard Map

\begin{tabular}{lll}
\hline Factors & Criteria & Source \\
\hline Geology & Geological types affecting the Seismic movement in the region. & Seed et al. 1988 \\
Soil & Soil types in the region. & Keefer and Schuster 1993 \\
Slope & Slope variations. & Algermissen 1989 \\
Land use & Land use and Management & Sadek 2004 \\
Earthquake Historical Events & Occurrence of previous disastrous events in the study region. & Besana and Ando 2005 \\
Fault Lines & Creating a buffer zone. & Onagh et al. 2012 \\
Roads & Buffer Zone &
\end{tabular}




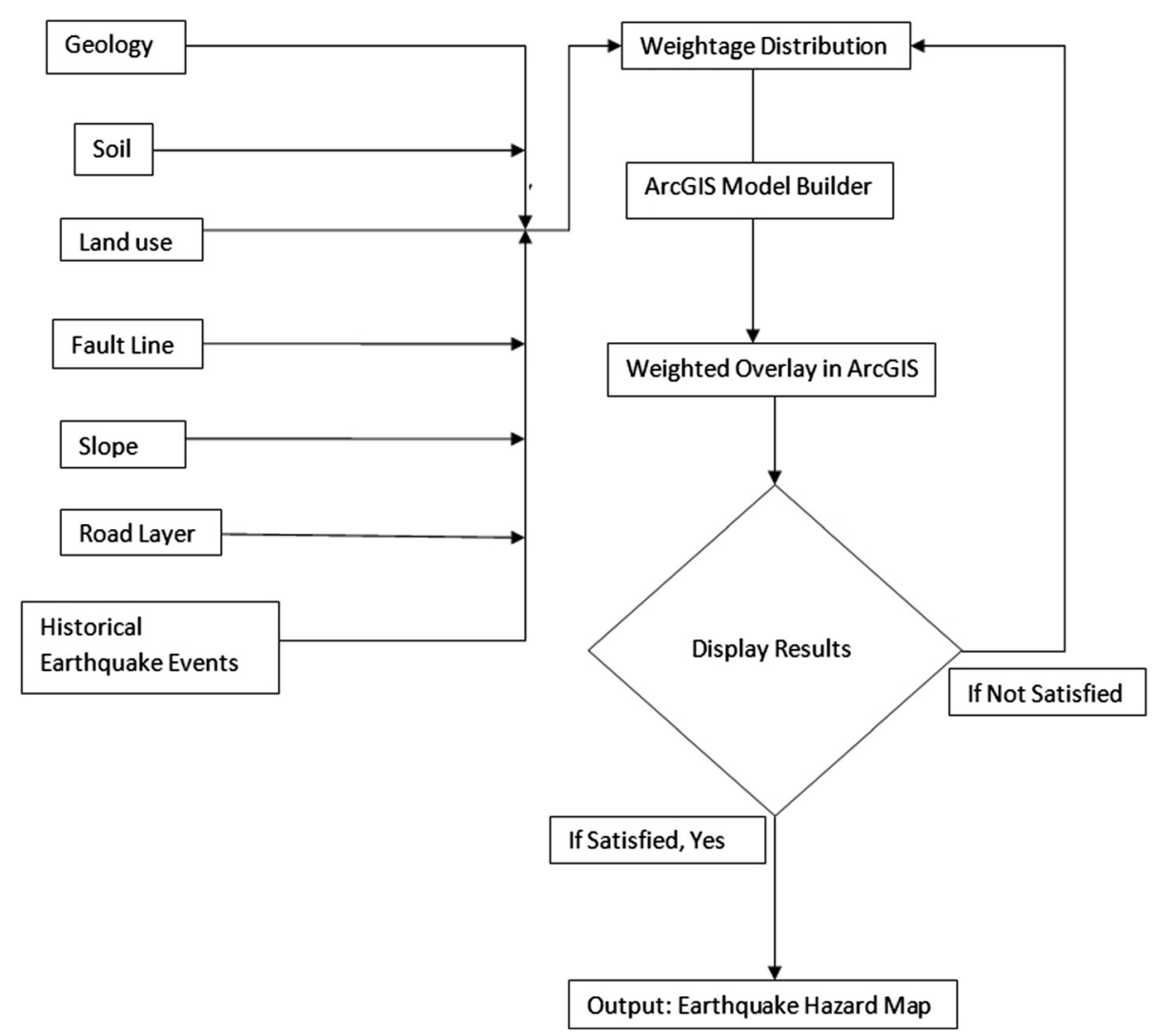

Figure 2 Flowchart.

ground to a certain distance and there is a direct relationship between intensity and distance of the epicenter for an earthquake (Skarlatoudis et al. 2004). These researchers stated that aftershock sequences $(1.7 \leq \mathrm{Mg} \leq 5.1)$, acquired from normal faulting events in Greece, have an epicentral distances of ( $3 \mathrm{~km} \leq \mathrm{R} \leq 40 \mathrm{~km})$ which are used to gain some insights into the engineering of small magnitude earthquakes. This had been taken into concern for our study area and buffer zones of 3, 5, 10 and $20 \mathrm{~km}$ were made.

The major earthquake sources around studied area are represented by the regional faults of the plate boundary. The Dibba Line falling in the region is almost parallel to the Zendan-Minab fault system with a NE-SW strike and dextral strike-slip motion (Lippard et al. 1982; Kusky et al. 2005). The Oman thrust found in the study area indicates the presence of some active tectonic structures in the Oman Mountains close to the UAE. In addition to field evidence of active faulting there is also historical evidence of earthquake activity in the region (Kusky et al. 2005). After consulting the other research works, buffer zones were taken for the fault line. These will vary from $<2 \mathrm{~km}$, $2-5 \mathrm{~km}, 5-10$ and $>10 \mathrm{~km}$ covering all the area of research for geohazards which may be triggered by any of the earthquake happening in the region.
A road constructed along slopes causes decrease in the load on both the topography and on the heel of the slope. A study conducted by Onagh et al. (2012) showed that the landslide hazard occurred within the range of buffer zone created as of $300-600 \mathrm{~m}, 600-1000 \mathrm{~m}$ and 1000-1500 m. This will be considered close to our research work as earthquake induced landslide can be a disaster for the cities living in the high risk zones and road network will play an important role in reaching the hazard site.

The spatial GIS model is generated by using the Model Builder application of ArcGIS software package. The vector weights were attained for each six criteria and a raster also by using spatial analyst tool's weighted overlay after appropriate classification of all seven factors. The model was built in GIS platform as it is easy to change the parameters in weighted overlay tool and other factors can also be included in that. The model consists of creation, calculation, classification, and summation of all related criteria. The geology, soil, land use, historical earthquake points, fault lines and slope are the basic inputs in here. Each parameter was given a rank and the applicable weightage from 0.10 to 1.00 . The earthquake catalog for magnitudes greater than 4 are 
Table 2 Weightage of hazard map factors

\begin{tabular}{|c|c|c|c|c|}
\hline Themes & Weightage & Individual class/features & $\begin{array}{l}\text { Rank/Value for } \\
\text { individual entity }\end{array}$ & Weightage* rank assigned \\
\hline \multirow[t]{6}{*}{ Geology } & 0.15 & Metamorphics & 1 & 0.15 \\
\hline & & Gabbros & 2 & 0.30 \\
\hline & & Chert/Limestone Facies & 3 & 0.45 \\
\hline & & Gabbros and Ultrabasics & 4 & 0.60 \\
\hline & & Fluviatile Deposits & 5 & 0.75 \\
\hline & & Ultrabasics-Peridotite & 6 & 0.90 \\
\hline \multirow[t]{2}{*}{ Soil } & 0.10 & Torrifluvents, torriorthents and rock outcrops & 1 & 0.10 \\
\hline & & Rock-outcrops, torripsamments and calciorthids & 2 & 0.20 \\
\hline \multirow[t]{3}{*}{ Slope (in percentage) } & 0.15 & Low $(0-30)$ & 1 & 0.15 \\
\hline & & Medium (30-60) & 2 & 0.30 \\
\hline & & High $(>60)$ & 3 & 0.45 \\
\hline \multirow[t]{5}{*}{ Land Use } & 0.10 & Green Areas & 1 & 0.10 \\
\hline & & Waterbodies & 2 & 0.20 \\
\hline & & Rock-outcrop, dunes and crushers & 3 & 0.30 \\
\hline & & Oil Tank & 4 & 0.40 \\
\hline & & Built-up & 5 & 0.50 \\
\hline \multirow[t]{4}{*}{ Earthquake Historical Events } & 0.25 & $20 \mathrm{~km}$ & 1 & 0.25 \\
\hline & & $10 \mathrm{~km}$ & 2 & 0.50 \\
\hline & & $5 \mathrm{~km}$ & 3 & 0.75 \\
\hline & & $3 \mathrm{~km}$ & 4 & 1.00 \\
\hline \multirow[t]{4}{*}{ Fault line $(\mathrm{km})$} & 0.20 & $10-30$ & 1 & 0.20 \\
\hline & & $5-10$ & 2 & 0.40 \\
\hline & & $2-5$ & 3 & 0.60 \\
\hline & & $<2$ & 4 & 0.80 \\
\hline \multirow[t]{3}{*}{ Road (m) } & 0.05 & 1500 & 1 & 0.05 \\
\hline & & 1000 & 2 & 0.10 \\
\hline & & 500 & 3 & 0.15 \\
\hline
\end{tabular}

used to describe where the future large earthquakes may occur (Allen and Kanamori 2003) making it more vital for our study.

\section{Results and Discussion}

The result discusses the spatio-temporal mapping and preparation of the hazard map.

\section{Spatio-temporal mapping of UAE Earthquakes}

As per the temporal analysis of earthquake distribution in UAE many points are first need to be considered. Within UAE, high density (57\% out of 108 earthquake incidences) of earthquake occurs in the northern and eastern emirates (Oman Thrust) (Figure 3). This area is dominated by mountains and the mountains themselves are the result of a process of uplift and thrust which took place over a period of 20 million years and which has left a series of jagged peaks rising to heights of over 1500 meter above sea level (UAE Atlas 1993). It is clear from Table 3 that the maximum number of earthquakes occurred in the Emirate of Fujairah therefore more details were carried out for Fujairah. Farshad et al. (2006) provided regional context about Fujairah Geology without detail analysis about earthquakes. They mentioned that the major earthquake sources are caused by the regional faults of the plate boundary and the secondary earthquake sources are represented by the local crustal faults that cross UAE mainly in the direction of NE, NW, N-S.

Fujairah Emirate, major part of the study area, covers an area of 1450 square kilometers. It is composed mainly of mountain series, hills, flatlands, oases, and some desert areas. The climate is semi-continental and temperature varies from one month to other depending on rainfall and humidity. Sixty two Earthquake events occurred in Fujairah in the period between 2002 and 2012. Only five of them $(8 \%)$ are within a buffer zone of $10 \mathrm{~km}$ from the 


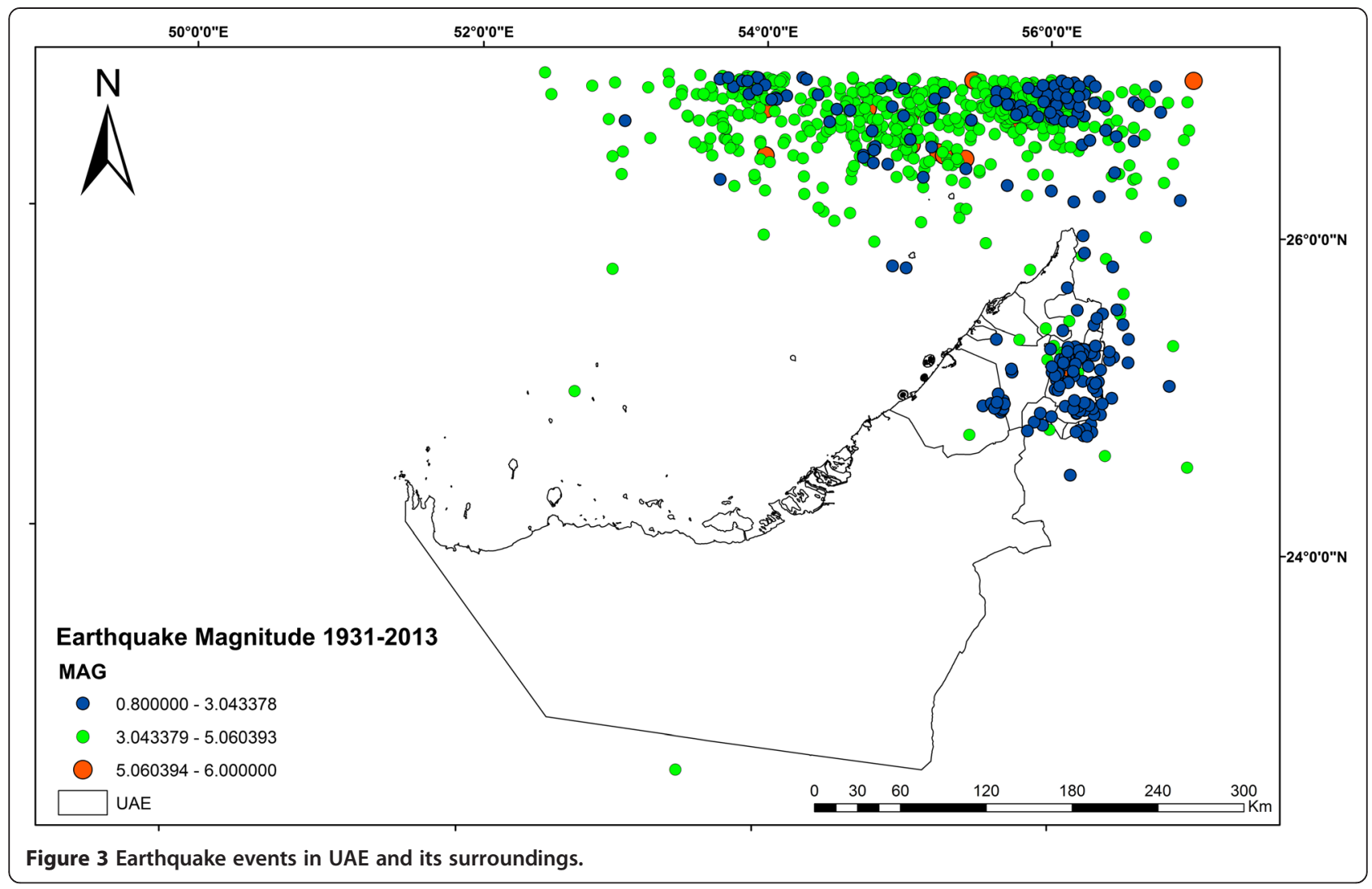

Fujairah main city with mean magnitude of 1.6. This indicates that during the last 10 years there is no earthquake felt, but may be recorded. On May 27, 2014 an earthquake hit Qeshm Island in south Iran (5.1 Magnitude, $10 \mathrm{~km}$ depth) and many cities in UAE felt with tremors (Al Bayan 2014). The magnitude variation can be divided into three types as mild, light and moderate which depend on the intensity with which they hit the area (Figure 4 ). The majority (55\%) of mild earthquake which ranges from 0.8-2.0 have the highest percentage followed by light and moderate intensity earthquake events comprises the lowest percentage which shows that there is low risk of high intensity earthquake likely to hit in the study region, but the frequency being increased in past few years are point of concern and it cannot be deniable by looking at the data that an earthquake may hit the country.

The year wise distribution of the earthquake events happened in the past 28 years with magnitude are

Table 3 Summary of earthquake by Emirates (1984-2012)

\begin{tabular}{llcc}
\hline Emirates & Magnitude range & Frequency & Percentage \\
\hline DUBAI & $0.9-3.8$ & 14 & 13 \\
FUJAIRAH & $0.8-5.1$ & 62 & 57 \\
MUSANDAM & $1.5-3.9$ & 6 & 6 \\
RAS AL KHAIMAH & $2.5-4.2$ & 2 & 2 \\
SHARJAH & $1.2-3.9$ & 24 & 22 \\
\hline
\end{tabular}

summarized in Table 4. This shows that majority of the events occurred in the past decade and the intensity is also increased from minor to light. The data were unevenly distributed in time, therefore it is difficult to deduce any annual or seasonal behavior.

Temporally, the maximum number of earthquake events (49\%) occurred in 2011 (Table 4) and this is in line with the USGS report that indicates the period 01 January to 12 October 2011 theearthquake activity (6.09.9 magnitude) reached its highest level in 20 years(USGS 2014b). This is a global phenomenon and UAE is also been affected by the sudden reaction of the plates across the world. The main cause may be increased tectonic movements for the major fault lines all over and this is of a concern for the authority as well as scientists and researchers.

In general, magnitudes for the study area at comparable distances were found to be 1.2 to 5.1 units on Richter scale for sites on Ultrabasic allochthonous unit carrying highest magnitude of earthquake. Another unit called Gabbros and Gabbros \& Ultrabasics carry earthquakes of minor magnitude with 0.8 to 2.9 on Richter scale. Such correlation between magnitude and site geology were reported by many researchers (Rahman et al. 2008).

Ground acceleration values as large as $0.8 \mathrm{~g}$ have been recorded by many agencies having seismic instruments installed on the ground with Richter magnitude as small 


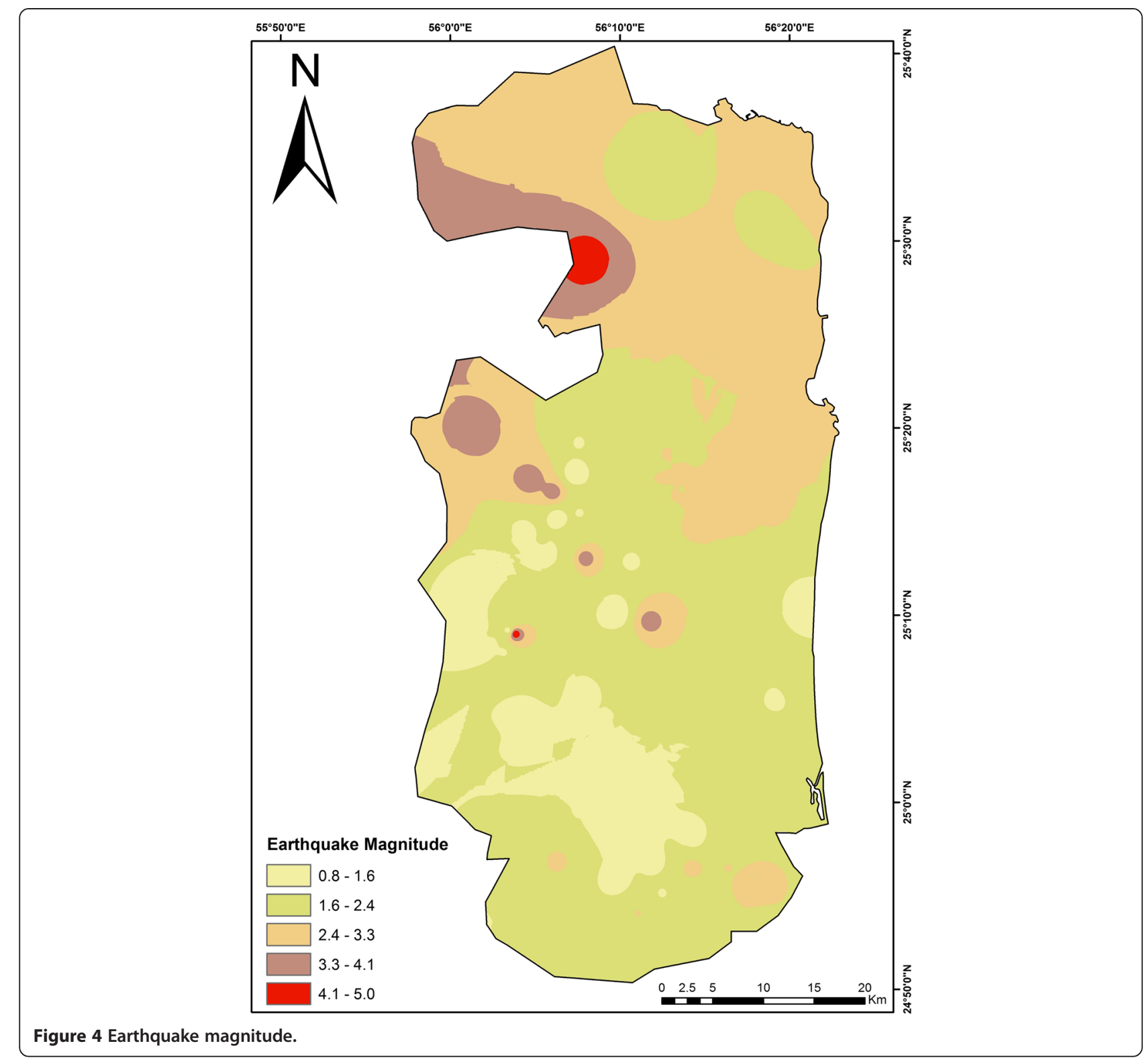

Table 4 Annual variation of earthquakes

\begin{tabular}{llll}
\hline Year & Number of earthquake & Percentage & Magnitude Range \\
\hline 1984 & 1 & 1 & 4.2 \\
1996 & 1 & 1 & 3.8 \\
2002 & 1 & 1 & 5.1 \\
2006 & 1 & 1 & 3.9 \\
2007 & 8 & 7 & $2.5-4.6$ \\
2008 & 12 & 11 & $2.4-4.0$ \\
2009 & 10 & 9 & $1.8-3.1$ \\
2010 & 19 & 18 & $0.9-2.7$ \\
2011 & 53 & 49 & $0.8-3.4$ \\
2012 & 2 & 2 & $3.8-4.0$ \\
\hline
\end{tabular}

as 3.5 and is highly influenced by local site conditions of the study area persuading ground motion. The scale of destruction also depends on the frequency of the vibrations and the fundamental period of the structure at risk. High frequency waves tend to have high accelerations but relatively small amplitudes of displacement. Low frequency waves have small accelerations but large velocities and displacements. During earthquake, the ground may vibrate at all frequencies from $0.1 \mathrm{~Hz}$ to $30 \mathrm{~Hz}$. If the natural period of building vibration is close to that of seismic waves, resonance can occur and causes the sway of structure to increase. Since the earthquake events can cause a vast destruction and loss of lives and property so they need to be taken seriously and proper planning should be done for evacuation process. 
Earthquakes can be associated with earth's emissivity and can unfold may unknown natural processes going on inside it. In this region of study, 40 villages and towns which represent $12 \%$ from the total number of villages in UAE (330) are found within $10 \mathrm{~km}$ from the epicenters. These comprises of some very important towns which are potential hub and contribute a lot in the growth of UAE. The port city of Fujariah, Kalba and the Wadi of Masafi (Rodgers et al. 2006) comes under the risk zone of any probable earthquake.

\section{Hazard Map}

Based on the critical values and score of the above taken parameters including slope, soil, geology, land use and earthquake points in consideration with fault lines, the potential risk zones of earthquake prone areas was calculated. Three susceptible ranks to evaluate the study were taken namely 1,2 and 3 . The earthquake risk areas falls under these ranking and been given the weightage from high to low for hazard mapping in the study region (Figure 5). Considering the earthquake risk, rank 1 was given as Low risk; rank 2 was given as medium risk zone and rank 3 as high risk. The high risk zone comprises of major earthquake events happened and are in the vicinity of the active fault line areas. This region also involves a number of crushers which may also be a secondary source of mild vibration occurring in the region.

The region is divided into three zones and the area is calculated of how much percentage each zone is contributing in this hazard study (Table 5). The maximum area comes under medium risk zone followed by high risk comprising of 13.76 percentage of the total study area while 10.27

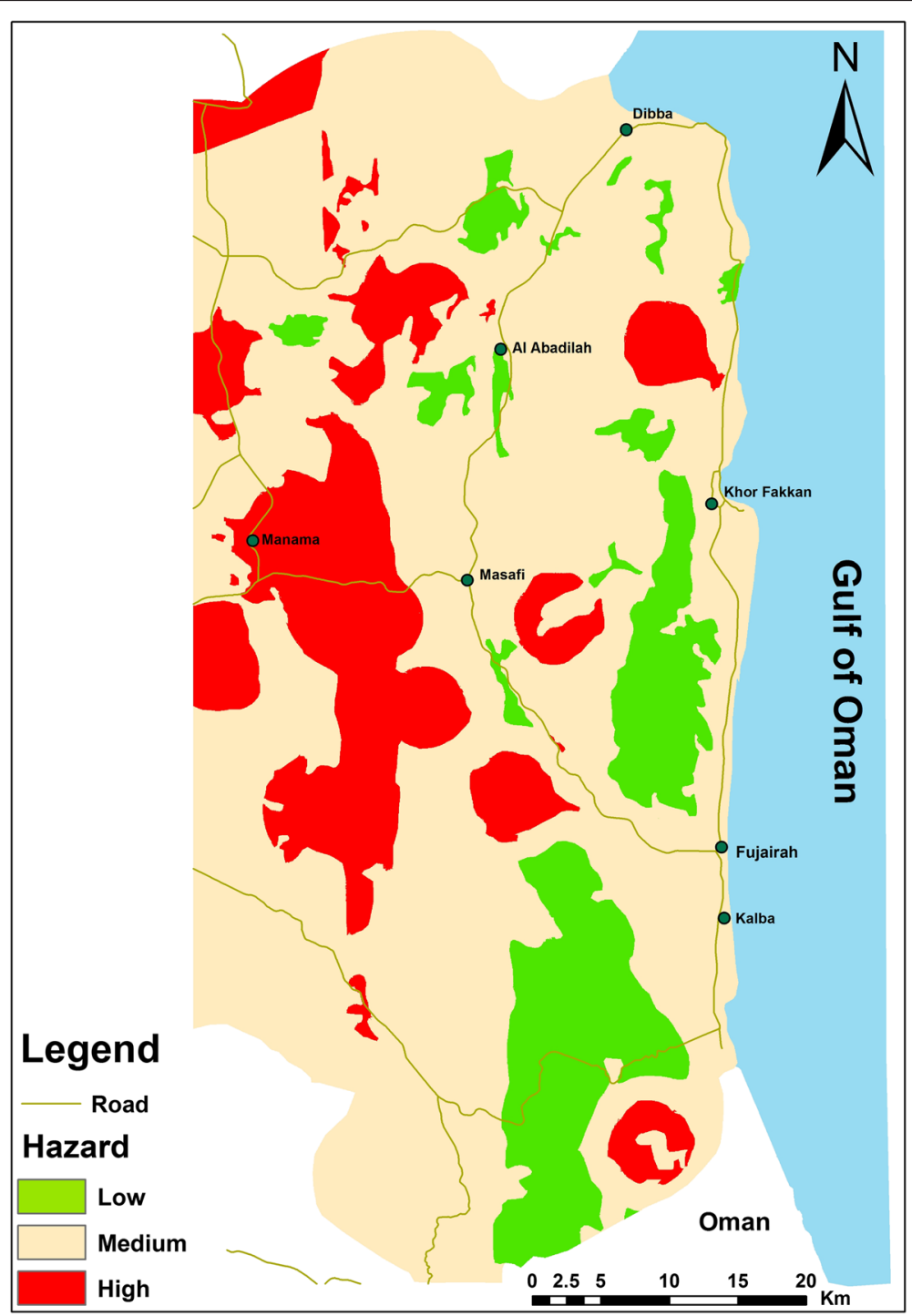

Figure 5 Hazard map. 
Table 5 Area with population on different scale

\begin{tabular}{llllll}
\hline Hazard scale & Area (Sq.Km.) & Percentage & No. of villages & Population affected (year 2005) & Percentage \\
\hline High & 550.33 & 13.76 & 16 & 17911 & 10.29 \\
Medium & 3039.05 & 75.97 & 25 & 152846 & 87.84 \\
Low & 410.62 & 10.27 & 4 & 3252 & 1.87 \\
Total & 4000 & 100 & 45 & 174009 & 100 \\
\hline
\end{tabular}

percent of the area falls under low risk zone. Total numbers of villages falling in the high and medium zones are around 41 with a population 170757 people residing in the vulnerable area comprising of $98 \%$ of total population approximately as per the data for the year 2005. However, this paper will give a holistic view about integration of all these parameters in the context of earthquake scenario. This shows the severity of the hazard events by earthquake or induced by it in the region and is an alarm to the authority for getting prepared for any worst situation that may happen in a gradual course of time. Maps produced using the method documented in this paper can be useful in emergency preparedness planning, lifeline siting and maintenance, critical-facility siting, long-term land-use planning, and a variety of other applications. Vulnerability differs from the concept of risk in being independent from any particular magnitude of a specific natural event, but dependent on the context in which that event occurs. Such a context is manifested through a set of ecological factors that may or may not be related to the geophysical events of natural hazards(Fischhoff et al. 1981).Some of these factors include the awareness of hazards, the condition of human settlements, public policy, and organized abilities in the field of disaster and risk management. Understanding the relative importance of these factors is vital to the establishment of impartial government policy and viable insurance schemes, and the identification of resources needed for emergency preparedness (Keeney 1995).

In the present work, the problem of vulnerability is not limited to a socially tempered response nor to a condition of potential exposure. Rather, vulnerability is thought of as a characteristic of the urban community that can be accessed through a combination of ecological factors associated with the physical conditions of the geographic space where the urban community is located and the social conditions of the population in that place. It is hypothesized that these physical and social conditions are so inextricably bound together in many disaster situations where the former can be used as indicative of the latter. The implication of this reasoning suggests a distinctly spatial approach to vulnerability analysis. Through this approach, areas with high levels of vulnerability (referred to hereafter as risk zones) are first located and differentiated from other areas within the study region. Then, these differences are utilized to improve our understanding of the relative importance of the ecological factors. Vulnerability analysis is thus conceived of as a spatial problem that involves searching the evidence of risk zones of vulnerability on the basis of multiple and differentially weighted evaluation criteria. Such a spatial perspective is substantially aided by the adoption of a GIS-based spatial multi-criteria analytical approach to tackle the ill-structured problem of vulnerability analysis.

Research on hazard continues to grow in scale and diversity. Many of the ideas provided by the social science community have taken root. For example, the shift in emphasis from hazards to disasters has continued and the spotlight on human vulnerability has been maintained (White et al. 2001). The relationship between a hazard and its probability can then be used to determine the overall degree of risk. Whilst damage to goods and the environment can be costly in economic and social terms, a direct threat to life is the most serious risk. Risk is sometimes taken as synonymous with hazard but risk has the additional implication of the chance of a particular hazard actually occurring. Hazard is best viewed as a naturally occurring or human-induced process, or event, with the potential to create loss. Risk is the actual exposure of something of human value to a hazard and is often regarded as the product of probability and loss (Okrent 1980).

Vulnerability, like risk and hazard, is a possible future state that implies high risk combined with an inability to cope. The term social vulnerability is used to define the susceptibility of social groups to potential losses from hazard events or society's resistance and resilience to hazards (Blaikie et al. 1994; Hewitt 1997). The concepts of vulnerability and multiple hazards in a place encompass both biophysical and social vulnerability, and are applied to many geographic domains ranging from the local to the global. The interplay of social, political, and economic factors interacting separately, in combination with one another, and with the physical environment creates a mosaic of risks and hazards that affect people and the places they inhabit.

Road is a critical facility that plays an important role during an emergency event. Relief and rescue operation are done efficiently if there are proper road networks. Distance from the road is important while calculating the probable number of population and building that can be served. Even though major area is under vulnerable zone, some places along the roadside are more prone to the 
hazard. The reason behind this is mainly due to the population residing in the proximity of mountains with steep slope and unstable geological condition. Cities like Masafi are situated in the vicinity of mountains with medium risk conditions and also major cities even though not falling under mountainous risk comes to a medium risk zone like Fujairah, Kalba, Khor Fakkan. This may be due to soil condition and earthquake events happened in the previous years.

\section{Conclusion}

This research represents an effort to study the temporal and spatial distribution of earthquakes in UAE between 1984 and 2012 and its correlation with population distribution and infrastructure. Earthquake events were found to occur in cluster basically in the eastern part of UAE and more precisely, near the Oman thrust. This fault line arouses due to the collision of Arabian plate with central Iranian Micro-continent (CIM) and is still in the phase of regular conflict. This results in some medium earthquake events with an intensity of 3.0 to 5.1 and also many minor tremors of 0.8 to 3.0. This represents the level of earthquake intensity that hit the area in the particular year frame. Temporally, the maximum number of earthquake events happening in the year 2011 and this in line with the USGS report that in 2011 the earthquake activity reached its highest level in 20 years.

This study was taken to analyze seven different base layers viz. geology, soil, slope, land use, historical earthquakes, fault line and road network using GIS model to create earthquake hazard map. The map is expected to increase the awareness for disaster prevention at the time of need. The study shows that areas near mountains are more vulnerable and the population near it is on a high risk zone.13.76 \% of total study area falls under high risk zone, $75.97 \%$ under medium risk, and $10.27 \%$ under low risk zone. The intensity of occurrence may not be high enough to cause a serious hazard but the frequency of the events is in much bigger concern. However, the accuracy of this study results depend on earthquake catalogue data and percent influence weight determination. Different planning purposes may need different criteria e.g. building, parks, factories, schools etc. Since this study gives a general overview about hazardous areas, the concerned authorities can take the output from this study as initial guide. They can change the criteria in the working model and can depict their own results as per their priorities and judgments. Other parameters like groundwater (Al-Farraj 2012) and crushers/mining (Mendecki and Lotter 2011) active in the region can also have a significant role in seismic activities and provide enough scope for further study.

\section{Competing interests}

The author declares that he has no competing interests.

\section{Acknowledgment}

The support for the research presented in this paper had been provided by the United Arab Emirate University-UAE National Research Foundation (NRF) The support is gratefully acknowledged. The views and conclusions are those of the author and should not be taken as those of the sponsor.

Received: 29 December 2014 Accepted: 16 March 2015

Published online: 08 May 2015

\section{References}

Abdalla JA, Al-Homoud AS (2004) Earthquake Hazard Zonation of Eastern Arabia. In: The 13th World Congress on Earthquake Engineering, Vancouver, B.C., Canada, 1-6August 2004

Abrams M, Bailey B, Tsu H, Hato M (2010) The ASTER global DEM. Photogrammetric Engineering\& Remote Sensing 76(4):344-348

Al Bayan Newspaper (2014) The Southern Iran earthquake of $5.1 \mathrm{MW}$ and $10 \mathrm{~km}$ depth has no effect on UAE. May 28. Al Bayan Newspaper, 12397, p. 20

Al-Farraj A (2012) Groundwater Over-Pumping and Recent Earthquakes in the Northern United Arab Emirates: A Natural Hazard Accentuated by Human Activity. Journal of Water Resource and Protection 4:800-806

Algermissen ST (1989) Techniques and parameters for earthquake risk assessment. Bulletin of The New Zealand national society for earthquake engineering, December,1989, Christchurch 22(4):202-218

Alimohammadi A (2005) Space Technology and Earthquake Prediction. In: The Proceedings of The Map Middle East, Dubai, UAE, 23-25 April 2005.

Ahmad AS, Pirasteh S (2004) Geological application of Landsat Etm for mapping structural geology and interpretation: Aided by Remote sensing and GIS. Int J Remote Sens 25(21):4715-4727

Allen RM, Kanamori H (2003) The potential for earthquake early warning in southern California. Science 300:786-789

Balaji D, Sankar R, Karthi S (2002) GIS Approach for Disaster Management through Awareness-An Overview. Paper presented at the proceedings of the 5th Annual International Conference-Map India, New Delhi, 6-8 February 2002

BBC (2013) Could GPS be used to predict earthquakes? http://www.bbc.com/ news/science-environment-17487482. Accessed 13 September 2013

Besana GM, Ando M (2005) The central Philippine fault zone: Location of great earthquakes, slow events and creep activity. Earth Planets Space 57:987-994

Blaikie P, Cannon T, Davis I, Wisner B (1994) At Risk: Natural Hazards. People's Vulnerability and Disasters, Routledge, London

Borcherdt R, Wentworth CM, Janssen A, Fumal T, Gibbs J (1991) Methodology for predictive GIS mapping of special study zones for strong ground shaking in the San Francisco Bay region, CA. paper presented at the 4thlnternational Conference on Seismic zonation, Stanford, California, USA, 26-29 August 1991

Brueckner HK, Medaris LG (1998) A tale of two orogens: the contrasting T-P-t history and geochemical evolution of mantle in high- and ultrahigh-pressure metamorphic terrains of the Norwegian Caledonides and the Czech Variscides. Schweizerische Mineralogische Und Petrographische Mitteilungen 78(2):293-307

Champatiray PK, Perumal RJ, Thakur VC, Bhat MI, Malik MA, Singh VK et al (2005) A quick appraisal of ground deformation in Indian region due to the October 8, 2005 earthquake, Muzaffarabad, Pakistan. Journal of the Indian Society of Remote Sensing 33(4):465-473

Farghaly AA (2014) Evaluation of Seismic Performance of Buildings Constructed on Hillside Slope of Doronka Village-Egypt. ISRN Civil Engineering Journal 2014 (Article ID:940923, 13 pages). http://dx.doi.org/10.1155/2014/940923

Farshad Jamali, S. M. Fatemi Aghda \& Alireza Aliyari (2006) Evaluation of seismic sources for hazard assessment in the Fujairah Emirate (UAE). Paper presented at the IAEG2006, the Geological Society of London, 6-10th September 2006, Nottingham, United Kingdom

Fischhoff B, Lichtenstein S, Slovic P, Derby SL, Keeney RL (1981) AcceptableRisk. Cambridge University Press, New York

Fujairah Statistics Center (2013) http://www.fscfuj.gov.ae/activities.html\#statconf. Accessed 09 December 2013

Glennie KW, Boef MGA, Hughes-Clarke MW, Moody-Stuart MN, Pilaar WFH, Reinhart BM (1974) Geology of the Oman Mountains. Verhandelingen Koninklijk Nederlasnds Geologisch Mijnboukundig Genootschap 31:423

Glennie KW, Boef MGA, Hughes-Clarke MW, Moody-Stuart MN, Pilaar WFH, Reinhart BM (1990) Inter-relationship of Makran-Oman Mountainsbelts of convergence. In: Robertson AHF, Searle MP, Ries AC (eds) The Geology and Tectonics of the Oman Region, vol 49, Geological Society Special Publication., pp 773-786 
Gnos E, Nicolas A (1996) Structural evolution of the northern end of the Oman Ophiolite and enclosed granulites. Tectonophysics 254:111-137

Grunthal G, Bosse C, Sellami S, Mayer-Rosa D, Giardini D (1999) Compilation of theGSHAP regional seismic hazard for Europe, Africa and the Middle East. Ann Geofis 42(6):1215-1223

Gulf News (2013) Iran Earthquake felt in UAE and Arabian Gulf. 9 May, 2013. http://gulfnews.com/news/uae/weather/iran-earthquake-felt-in-uae-andarabian-gulf-1.1168528. Accessed 10 September 2013

Hayakawa YS, Oguchi T, Lin Z (2008) Comparison of new and existing global digital elevation models: ASTER G-DEM and SRTM-3. Geophys Res Lett 35, L17404. doi:10.1029/2008GL035036

Heki K, Ping JS (2005) Directivity and apparent velocity of the coseismic ionospheric disturbances observed with a dense GPS array. Earth Planet Sci Lett 236:845-855

Henning, BD (2011) Gridded cartograms as a method for visualising earthquake risk at the global scale. Journal of Maps. doi:10.1080/17445647.2013.806229

Hewitt K (1997) Regions of Risk: A Geographical Introduction to Disasters. Longman Harlow, London

Hirt C, Filmer MS, Featherstone WE (2010) Comparison and validation of the recent freely available ASTER-GDEM ver1, SRTM ver4.1 and GEODATA DEM-9S ver3 digital elevation models over Australia. Aust J Earth Sci 57(3):337-347

ISC- International Seismological Centre (2013) http://www.isc.ac.uk/iscbulletin/. Accessed 02 December 2013

Kanli Al, Tildy P, Pronay Z, Pinar A, Hemann L (2006) Vs mapping and soil classification for seismic site effect evaluation in Dinar region, SW Turkey. Geophysics Journal International 165:223-235

Keefer DK, Schuster RL (1993) A method for predicting slope instability for earthquake hazard maps.Preliminary Report: Association of Engineering Geologists Special. Publication 10:39-52

Keeney RL (1995) Understanding life threatening risks. Risk Anal 15:627-637

Khaleej Times (2013) Earthquake in Iran, Tremors felt in UAE. 11 May, 2013. http:// www.khaleejtimes.com/index00.asp. Accessed 15 July, 2013

Kusky T, Robinson C, El-Baz F (2005) Tertiary-Quaternary faulting and uplift in the northern Oman Hajar Mountains. J Geol Soc 162(5):871-888

Laefer DF, Alison K, Pradhan A (2006) The Need for Baseline Data Characteristics for GIS-based Disaster Management Systems. Journal of Urban Planning and Development 132(3):115-119

Lillesand TM, Kiefer RW, Jonthan WC (2008) Remote Sensing and Image Interpretation 6thedn. John Wiley and Sons, New York

Lindell MK, Prater CS (2002) Assessing Community Impacts of Natural Disasters. Natural Hazards Review. doi:176-185. 10.1061/(ASCE)1527-6988(2003)4:4(176)

Lippard SJ, Smewing JD, Rothery DA, Browning P (1982) The geology of the Dibba Zone, northern Oman Mountains; A preliminary study. J Geol Soc 139(1):59-66

Lippard SJ (1983) Cretaceous high pressure metamorphism in NE Oman and its relationship to subduction and ophiolite nappe emplacement. J Geol Soc 140(1):97-104

Mendecki AJ, Lotter EC (2011) Modeling Seismic Hazard for Mines, paper presented at the Australian Earthquake Engineering Society Conference, Barossa Valley, South Australia,18-20 November 2011

Miles SB, Ho CL (1999) Applications and issues of GIS as tool for civil engineering modeling. Journal of Computing in Civil Engineering, ASCE 13(3):144-161

Mwafy AM (2010) Analytically derived fragility relationships for the modern high-rise buildings in the UAE. The Structural Design of Tall and Specia Buildings 21:824-843

NCMS-UAE National Center for Meteorology and Seismology (2014) http:// seismology.ncms.ae/. Accessed 23 January 2014

Okrent D (1980) Comment on societal risk. Science 208:372-375

Onagh Md, Kumra VK, Rai PK (2012) Landslide Susceptibility Mapping in a part of Uttarkashi district (India) by multiple linear regression method. International Journal of Geology 2(2):102-120

Pirasteh S, Woodbridge K, Rizvi SM (2009) Geo-information technology (GiT) and tectonic signatures: the River Karun \& Dez, Zagros Orogen in south-west Iran. Int J Remote Sens 30(1-2):389-404

Pirasteh S, Pradhan B, Safari H (2011) Coupling of DEM and remote sensing based approaches for semi-automated detection of regional geo-structural features in Zagros Mountain. Iran Arabian Journal of Geosciences doi:10.1007/s12517-011-0361-0

Pirasteh S, Li J, Mollaee S (2014) Satellite-based detection of compounding tectonic activities effecting on column of ozone and thermal infrared precursor to earthquake occurrence. Disaster Advances Journal 7(12):32-40
Pirasteh S, Li J, Attarzadeh I (2015) Implementation of the damage index approach to rapid evaluation building resistance for earthquakes. Earth Science Informatics. doi:10.1007/s12145-014-0204-0

Rahman MA, Rahman SM, Rezual Islam M, Keramat M (2008) The study of geological constituents of mid-atlantic oceanic crust with the application of attributes in seismic profiles. Journal of Geological Society of India 71:717-723

Robertson AHF, Searle MP (1990) The northern Oman Tethyan continental margin; stratigraphy, structure, concepts and controversies. In Robertson, AHF, Searle, MP, Ries, AC (eds) The Geology and Tectonics of the Oman Region, vol. 49, Geological Society of London

Rodgers A, Fowler AR, Abdullah MS, Al-Amri AA-E (2006) The March 11, 2002 Masafi, United Arab Emirates earthquake: Insights into the seismotectonics of the northern Oman Mountains. Tectonophysics 415:57-64

Roustaei M, Nazi H, and Amirmotallebi N (2005) The Seismotectonic and Zonation Map of Salmas Vastness by GIS modeling according to Landsat Satellite Images (ETM+) and Aeromagnetic data. Paper presented at the Map Middle East, 23-25 April, 2005, Dubai, UAE

Roy PS, WestenCJ WK, Lackhera RC, Chapari ray PK (2000) Natural disasters and their mitigation-Remote Sensing and Geographical Information System Perspectives. Indian Institute of Remote Sensing Publication, Dehradun

Sadek AW (2004) Seismic map for the state of Kuwait. Emirates Journal for Engineering Research 9(2):53-58

Safari Hojjat O, Saeid P, Shattri M (2011) Role of Kazerun Fault for localizing oil seepage in Zagros Mountain Iran: an application of GiT. Journal of Remote Sensing 32(1):1-16

Seed HB, Romo MP, SunJ JA, Lysmer J (1988) The Mexico earthquake of September 19,1985: Relationship between soil conditions and earthquake ground motions. Earthquake Spectra 4:687-729

Skarlatoudis AA, Theodulidis N, Papaioannou C, Roumelioti Z (2004) The dependence of peak horizontal acceleration on magnitude and distance for small magnitude earthquakes in Greece. In: 13th World Conference on Earthquake Engineering, Vancouver, Canada, August, 2004

The National (2013) New earthquake code for Dubai's tall buildings. http://www.thenational.ae/uae. Accessed 15 July, 2013

UAE Atlas (1993) UAE Atlas. UAE University Publication, Al Ain, UAE

USGS Earth Explorer (2013) http://earthexplorer.usgs.gov/. Accessed December 2013

USGS (2013) Earthquake Archive Search \& URL Builde http://earthquake.usgs.gov/ earthquakes/search/. Accessed 17 July 2013

USGS (2014a) Hazards http://earthquake.usgs.gov/hazards/. Accessed 15 July 2014

USGS (2014b) Reports http://www.sott.net/article/236229-USGS-Reports-RecordNumber-Of-Strong-Earthquakes-In-2011. Accessed 10 July 2014

Wang F (2014) Reducing geo-disasters for improving the relationships between geoenvironment and society. Geoenvironmental Disasters 1:3. doi:10.1186/ s40677-014-0003-4.

White GF, Kates RW, Burton I (2001) Knowing better and losing even more: the use of knowledge in hazards management. Environmental Hazards 3:81-92

\section{Submit your manuscript to a SpringerOpen ${ }^{\circ}$ journal and benefit from:}

- Convenient online submission

- Rigorous peer review

- Immediate publication on acceptance

- Open access: articles freely available online

- High visibility within the field

- Retaining the copyright to your article

Submit your next manuscript at $>$ springeropen.com 